\title{
Gashaw Arutie Asaye* Static locative expressions in Amharic
}

\author{
https://doi.org/10.1515/jall-2021-2017
}

\begin{abstract}
This paper describes the semantics of static locative expressions in Amharic, particularly the variety spoken in Godzdzam. The analysis shows that the semantic category of a site subsumed under Path is exclusively expressed by an adposition. The adpositions can be specific and general locatives. The specific locatives show a specific type of topological relation (for instance, verticality as in tat ft 'below, under,' horizontality as in fit 'front,' containment as in wist' 'in') between figure and ground entities, but not the general locatives. Besides, static positional verbs encode the conflation of the fact of locatedness with a manner of the positioning of a figure. Based on Talmy's Motion event typology, the present study has identified that Amharic uses a satellite-framed pattern in static locative constructions exclusively. Moreover, based on Ameka \& Levinson's typology of locative predication, Amharic can be classified under type Ia where a language uses a dummy verb in basic locative construction.
\end{abstract}

Keywords: adpositions; Amharic; locative construction; motion event typology; semantics

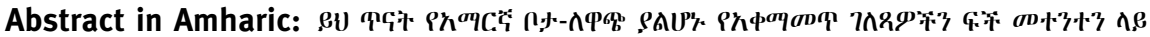

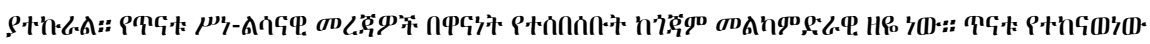

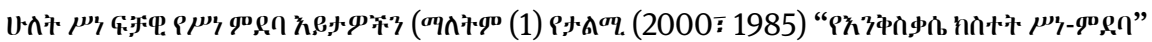

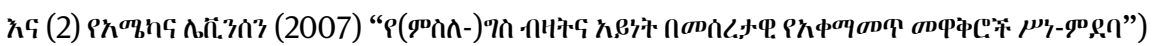

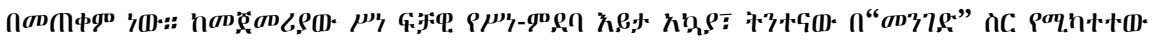

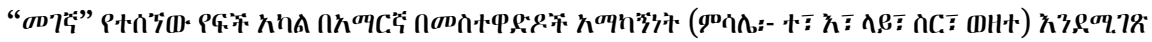

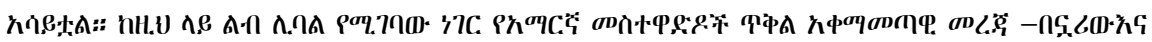

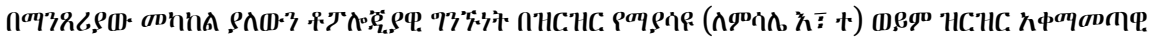

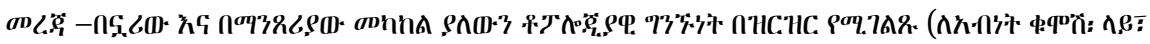
小和

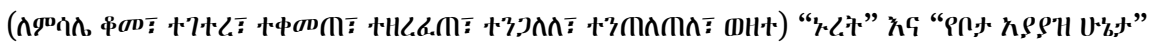

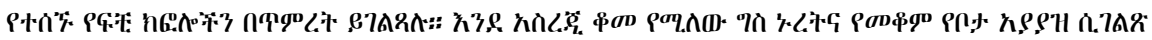
н中am
\end{abstract}

*Corresponding author: Gashaw Arutie Asaye, Department of Ethiopian Languages and Literature, Faculty of Humanities, Bahir Dar University, Bahir Dar, Ethiopia,

E-mail: gashgebu@gmail.com 


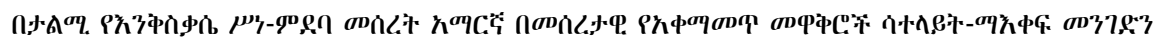

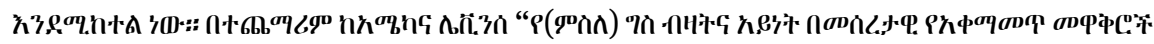

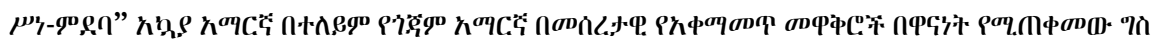

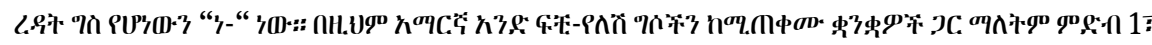

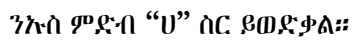

\section{Introduction}

In this paper, I discuss the semantics of static locative expressions in the Godzdzam variety of Amharic. I show that the semantic component of site is exclusively expressed by adpositions. The adpositions can be specific or general locatives. The specific locatives indicate types of topological relations between the figure and ground entities, for instance: verticality (e.g. tat $\int \mathbf{t} \int$ 'below, under'), horizontality (e.g. fit 'front'), containment (e.g. wist' 'in, inside'). The general locatives do not express such relations. Besides, static positional verbs encode the conflation of the fact of locatedness with a manner of the positioning of a figure. Based on Talmy's $(1985,2000,2007)$ motion event typology, in the present study it is claimed that Amharic exclusively uses a satellite-framed pattern in static locative constructions. The typical basic locative construction (henceforth BLC) of Amharic is a copular construction with the verbal copula nə- although the language has other alternative locative constructions (cf. Section 4). Following Ameka and Levinson's (2007) typology of locative predicates, this means that Amharic is a type Ia language.

Amharic is a Semitic language spoken in Ethiopia. It serves as a de facto lingua franca in cities and towns of the country (cf. Meyer 2011b: 1,213, 2006: 129; Hudson 1997: 457) and is the working language of the federal government. It has five main regional varieties. These are: the Addis Ababa variety, which is also known as 'the standard variety', Godzdzam, Gondər, Jəwa (Mənz) and Wəllo varieties (Meyer 2011a: 1,181-82; Zelealem 2007: 479, 2017: 1). These regional dialects have their own specific phonological, morphological, and lexical features. However, there are cases in which a particular variety may share some peculiar features with another dialect. Also, there seem to be minor variations within a regional dialect, which need detailed research (cf. Zelealem 2017: 2).

Amharic is one of the well-described Ethiopian languages. However, semantics is relatively a neglected topic in Amharic linguistics. The present paper deals with the semantics of static locative expressions in Godzdzam Amharic.

The paper is organized as follows: Section 2 presents some relevant typological properties of Amharic, the theoretical background of the study, and the methods for collecting data. Section 3 discusses the way semantic components of spatial 
events, particularly stationary location events are expressed in the language. Section 4 examines basic locative constructions in Amharic. In Section 5, I summarize the discussion and draw conclusions.

\section{Theoretical background and methods}

This paper is guided by two typological perspectives: (a) Talmy's Motion event typology and (b) typology of locative predicates proposed by Ameka and Levinson (2007). In this subsection, I give a brief introduction to these typological approaches.

\subsection{Motion event typology}

Talmy (2000: 25, 2007: 70) defines Motion event (with capital M) as an event or situation that comprises an object (Figure) moving or located with respect to another object (Ground). It subsumes stationary location and motion (Talmy 2007: 70). The complex Motion event is made up of a framing event (main event) and a subordinate event (co-event) (Talmy 2000: 215).

The main event of Motion can be analyzed into four basic semantic elements: Motion, Path, Figure, and Ground. Figure entity is an entity which is conceptualized as moving or located with respect to another object (cf. Talmy 2000: 25). Ground entity is the entity which is conceptualized as reference entity. Talmy (2014: 3) states that Path is the core schema of the framing event. The Motion component (with a capital $\mathrm{M}$ ) refers to the occurrence per se of motion or locatedness in the event (Talmy 2000: 25, 2007: 70). The Path (with capital P) component of Motion event is the trajectory that is followed or the site that is occupied by the figure with respect to the ground.

On the other hand, the subordinate event (Co-event) consists of manner, cause, precursion, enablement, and concomitance (Talmy 2000: 27). Note that the Co-event is conceived as support relation to the framing event. Semantically, the Co-event is more primary and vivid than the main event because the framing event is abstract, while the subordinate event tends to be more perceptually palpable (Talmy 2000: 219-20).

Based on the characteristic pattern in which the conceptual structure of the macro-event is mapped onto the syntactic structure, languages of the world can be classified into two categories -verb-framed languages and satellite-framed languages (Talmy 2000: 222, 2007: 153, 2014: 2). Verb-framed languages are languages that characteristically map the core schema of framing event (i.e., Path) into the 
verb whereas satellite-framed languages characteristically map the core schema onto a satellite and/or a preposition. According to Talmy (2014: 2), the term "satellite" refers to "a constituent in construction with the main verb (root) and syntactically subordinate to it as a dependent to a head." And the term "preposition" can be defined as "a constituent in construction with an NP that could consist of a preposition and/or postposition and/or affix on the noun of the NP." Regarding the mapping of the subordinate event, satellite-framed languages map the Co-event into the main verb. On the other hand, verb-framed languages map the Co-event either onto the satellite or into an adjunct (an adpositional phrase or a gerundive type constituent) (Talmy 2000: 222).

However, Huang and Tanangkingsing (2005), Pourcel and Kopecka (2005), and Slobin (2004) a.o., show that some languages do not fit in these typological patterns. Thus, Slobin (2004: 244) added a third motion-framing typology, 'equipollently-framed category', in which a language may express path and manner by equivalent grammatical forms. Equipollently-framed languages include: (a) serialverb languages in which manner and path verbs come consecutively; (b) bipartiteverb languages in which both manner and path are expressed in a verb; (c) preverb languages in which both manner and path may be expressed in the preverbs (see Slobin 2004: 249, 2006: 65).

Although Motion event consists of movement and stationariness (Talmy 2000: 25, 2007: 70), a number of previous studies including those on Ethiopian languages (e.g., Debela 2007; Meyer 2007; Treis 2007; Wakasa 2016) determine the typology of Motion events of a language only based on movement expressions. This makes their claims on Motion event typology of a language incomplete. This is because while some languages like English use the same pattern in both movement and location expressions, other languages such as Amharic differentiate these. For instance, Talmy (2000: 26) takes both English movement and location expressions into account and shows that English employs a satellite-framed Motion construction. Consider the following examples:

1. Motion: The pencil rolled off the table.

2. Location: The pencil lay on the table (Talmy 2000: 26).

In these utterances, Paths (i.e., a path and a site) are encoded by off and on, respectively. And the conflation of Motion and Manner is lexicalized in the verbs rolled and lay.

The present study demonstrates variability of Motion construction patterns between movement and static locative expressions. As we will see in Section 3, Amharic uses a satellite-framed pattern in stationary location constructions exclusively. But it predominately employs a verb-framed pattern in complex clauses of movement expressions as reported in Wakasa (2016: 154). 


\subsection{Typology of locative predicates}

Languages of the world deploy different classes of linguistic units e.g., adpositions, nominal predicates, case inflections, locative verbs when expressing basic location (Levinson and Wilkins 2006b: 16). The term basic location construction refers to the construction that is used in responses to "where - questions" (i.e., "Where is the X?") (Levinson and Wilkins 2006a: 514, 2006b: 15).

Ameka and Levinson (2007: 863-64) identified four basic types of locative predication based on the size and semantic type of verbs used in the BLC (i.e., type 0 , type I, type II and type III). Type 0 includes languages that do not have verbs in a locative statement. Type I refers to languages that have a single locative verb (or suppletion under grammatical conditioning). The locative verb can be (a) a copula or (b) a locative (+existential). Type II comprises languages that employ a small contrastive set of locative verbs (3-7 verbs). The verbs can be (a) postural or (b) ground space denoting verbs. The last type, Type III, includes languages that use a large set of dispositional verbs (9-100 verbs). Ameka and Levinson (2007: 864) assert that genetically, typologically, and areally related languages can belong to different types of locative predication typology.

As will be shown in more detail in Section 4, Amharic employs three types of constructions: (1) a construction with a generic locative verb, (2) a construction with the copula verb nə- 'be' and, (3) a construction with an existential copula all'exist'. However, the typical BLC of the language is a construction that involves the verbal copula nə-. In this study, I claim that Amharic belongs to type Ia in the typology of locative predicates developed by Ameka and Levinson (2007).

On the other hand, the preference for the use of positional verbs and copulas or existential expressions can be used to classify languages as positional focus and existence focus. Languages whose speakers tend to use positional verbs are said to be positional focus languages, and those in which speakers frequently employ copula or existential constructions are said to be existence focus (Durst-Anderson 2011 cited in Ng 2014: 338). Since the typical BLC of Amharic is a copular construction, Amharic represents an existence focus language.

\subsection{Methods and data collection}

The data used in this paper are from the Amharic dialect of Godzdzam. They were mainly collected through elicitation and double checked with various speakers. The process was supported by Bowerman and Pederson's (1992) topological relations picture series. This widely used stimuli kit is prepared to obtain linguistic expressions of spatial relations between figure and ground entities and it includes 
a one-page instruction sheet. Following the procedure, I showed the picture stimuli to the consultants individually and elicited possible locative descriptions that are natural ways of answering the "where" question about entities in the pictures. In situations where the participants are not able to identify objects in the stimuli, I explained the scenes to the participants. For example, if picture 02 of TRPS is not clear to the participant, I describe the stimulus to the informant as follows: the picture in the yellow color is a spoon and the picture in the black color is a towel. Now, you are going to answer the question "Where is the spoon?" Also, I applied real scenes of the positioning of human figures as stimuli. For the elicitation, fifteen consultants from different Godzdzam areas namely, Mot'a, Dəbrəwork', Dəbrə Mark'os, K'warit, and Yismala have participated. See Table 1 for the demographic information on the consultants.

Table 1: Demographic information of the consultants.

\begin{tabular}{lllllr}
\hline Consultants' code & Location & Sex & Occupation & Educational level & Age \\
\hline 01 & Yismala & Male & Priest & Church education & 61 \\
02 & Yismala & Female & Farmer & Non-literate & 38 \\
03 & Yismala & Female & Teacher & BA degree & 29 \\
04 & K'warit & Male & Priest & Church education & 74 \\
05 & K'warit & Male & Teacher & MA degree & 33 \\
06 & K'warit & Female & Home_employed & Non-literate & 46 \\
07 & Dəbrə Mark'os & Male & Priest & Church education & 69 \\
08 & Dəbrə Mark'os & Male & Teacher & BA degree & 26 \\
09 & Dobrə Mark'os & Female & Home_employed & Grade 10 & 37 \\
10 & Dəbrəwork' & Male & Priest & Church education & 72 \\
11 & Dəbrəwork' & Male & Farmer & Non-literate & 44 \\
12 & Dobrəwork' & Female & Teacher & BA degree & 36 \\
13 & Mot'a & Male & Priest & Church education & 67 \\
14 & Mot'a & Female & Farmer & Non-literate & 51 \\
15 & Mot'a & Female & Home_employed & Grade 12 & 34 \\
\hline
\end{tabular}

\section{Static locative events}

In this section I discuss how semantic elements such as locatedness, site, and manner in the sense of Talmy's (1985, 2000, 2007) lexicalization patterns are encoded in Amharic. Semantic elements can be coded in different linguistic forms that belong to different categories such as verbs, adpositions, or satellites or a combination of these (Talmy 2000: 66-67, 2007: 21).

Amharic uses verbs such as, k’om- (< k’əwwəm-) 'stand', tək’əmmət'- 'sit', tənt'ələt't'əl- 'hang' and adpositions, e.g., tə- 'at', laj 'on' to express semantic 
elements (locatedness, site, manner) of a static location. Site is exclusively expressed by adpositions. Verbs express locatedness conflated with manner, as illustrated in example (1).
a. təmari (tə/i) $=$ bərr
laj k’əwwəm- ə > [k'omə]
student at $=$ doorstep on stand-3sG.M
'A student stood at the doorstep.'

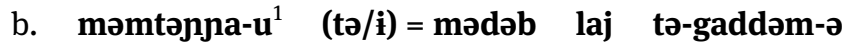
patient-DEF at = platform on MID-lie-3sG.m
'The patient lay on the platform.'

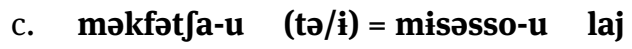
key-DEF at = pillar-DEF on
tə-nt'əlt'il-o-all > [tənt'əlt'il'wall]
PASs-hang.cVB-3sG.M-AUX
'The key is hung on the pillar.'

In these examples, the semantic element of Site is encoded by the postposition laj 'on'. Information about the Path in these static locative sentences is distributed among prepositions to or i 'at' and postpostions. On the other hand, Amharic static locative verbs do not portray information about the site of locatedness. In the semantic analysis of Amharic verbs including static verbs, semantic elements such as locatedness and type of positioning are associated with verb roots (cf. Mengistu 2010: 291). The combination of the semantic elements such as locatedness and manner related to position (i.e., 'standing', 'lying', and 'hanging'), in these examples, are encoded in the verb roots / $\mathbf{k}$ '-w-m/ 'stand', /g-d-m/ 'lie', and /t'-l-t'-l/ 'hang'. Thus, a single static verb root expresses manner conflated with locatedness. For instance, in (1a), the root / $\mathbf{k}^{\prime}-\mathbf{w}-\mathbf{m} /$ of the verb k'om (< k'əwwəm-) 'stand' denotes standing position of the figure (i.e., təmari 'student') conflated with the event of locatedness. In (1d), the root /g-d-m/ of the verb təgaddəm- 'lie' encodes the combination of locatedness and lying position of the figure (i.e., məmtəuna 'patient'). In example (1c), the root /t'-l-t'-1/ of verb tənt'ələt't'il'hang' lexicalizes the conflation of hanging position of the figure (i.e., məkfət $\int \mathbf{a}$ 'key') and locatedness. This implies that the relationship between the semantic elements and surface elements in Amharic is not one-to-one. It is two-to-one since two semantic elements are realized in a single verb root.

In static locative expressions, constructions with the verbal copulas nə-‘be' and all- 'exist', and with the generic locative verb ji-ggənj-all (< ji-tgənn-all) 'be

$\mathbf{1}$ When the morpheme $-\mathbf{u}$ is attached to stems ending with vowels, it changes to $-\mathbf{w}$ as in məmtənja-u > məmtənjaw 'the patient' and nə-u > nəw 'it is.' Hereafter, I only use the phonemic form. 
found' can also be used (for details about their contexts of use see Section 4). Such locative predicates are neutral to spatial relations; they do not convey information about the semantic category of a site. Note that the copula nə-links the elements in the locative construction while the existential copula all- expresses the fact of locatedness [+existence]. Besides, the verb ji-ggəjnn-all (< ji-tgənjn-all) encodes the semantic notion of locatedness. Consider the following example.

\section{(2) kot-u (i/tə) $=$ məsk'ija-u laj nə-u \\ coat-DEF at $=$ hanger-DEF on COP-3sG.M}

'The coat is on the hanger.' (TRPS 09)

In (2), Path, more specifically, a site is merely expressed by the adpositions i-/təand laj. Therefore, the utterance in (2) substantiates the claim that Amharic has a satellite-framed construction in static locative expressions. The copula verb nə-u in this example can be replaced by allə 'exist' or jiggənnall 'be.found' without any semantic difference.

\subsection{Verbs $^{2}$}

Amharic has several positional verbs expressing the conflation of locatedness and manner related to positioning of a figure at a site. Such verbs convey information about the situation of locatedness (lack of motion) and also the posture of a (human) figure at a site. They can be termed manner conflated static posture verbs. Based on the positioning types of the figure, they can be classified into four categories: (a) verbs of standing, (b) verbs of sitting, (c) verbs of lying, and (d) verbs of hanging. ${ }^{3}$ With the exception of verbs of hanging, Amharic positional verbs are

2 In this paper, "positional verbs" in Amharic refer to those simple verbs expressing the position or configuration of the located figure. Also, the verbs that appear in the answer for scenes of the stimuli are listed. And they are grouped based on their semantic similarity. Note that a locative description with complex predicates (e.g., k'ut't'it't' al- 'squat') can appear in Amharic static locative expressions. But the core meaning resides in the ideophone as in k'ut't'it't' 'squat'. Moreover, the verbal copulas and the generic locative verb are not included in this subsection because the semantic contents of such verbs have been discussed Section 3.1.

3 The morpheme to- has multiple inter-related functions. With verbs of hanging, to- is interpreted as passive marker. With positional locative verbs which are intransitive, tə- renders the reflexive. Based on transitivity classes mentioned in Mengistu (2000:313), Amharic positional locative verbs can be grouped under "unaccusative intransitive" verbs which encode a state. Besides, with verbs of hanging, the morpheme to- represents the meaning of medio-passive and passive depending on the type of the subject. If the subject is animate, it can be used as a medio-passive, if not, it is interpreted as passive (for details about the nature of tə- cf. Bezza 2011: 61-64; Mengistu 2000: 325-27; Lesalu 1995: 462-67). 
mainly used when locating a human figure. In the following sections I briefly discuss the four verb categories one by one.

\subsubsection{Verbs of standing}

The term "verbs of standing" refers to static verbs denoting the standing position of the figure while locating it at a site. In Amharic, verb roots which represent such semantic elements include /k'-w-m/ of the verb k'om- (< k'əwwəm-) 'stand', /b-g-r/ of the verb təbəggər- 'stand around idly', and /g-t-r/ of the verb təgəttər'stand erect'.

$$
\begin{aligned}
& \text { ləmman } \quad(\text { tə/i) }=\text { dədzdzaf laj /k’əwwəm-ə/ > [k'omə] } \\
& \text { beggar at = doorstep on stand-3sG.m } \\
& \text { 'A beggar stood at the doorstep.' }
\end{aligned}
$$

In example (3), the root /k'-w-m/ of the verb stem k'om- 'stand' expresses the standing position of the figure ləmman 'beggar' while locating the latter at the site dədzdzaf 'doorstep'. The semantic component of site, in this example, is represented by the combination of the prepositions tə- or $\mathbf{i}$ - and the postposition laj. Therefore, verbs derived from the stated roots are said to be manner (i.e., standing position) conflated static verbs.

\subsubsection{Verbs of sitting}

By "verbs of sitting” we refer to static verbs encoding the sitting type of positioning of the figure at a site. Like verbs of standing, the verbs of sitting are manner conflated verbs because they designate the combination of the fact of locatedness and sitting position of the figure. The verbs tək'əmmət'- 'sit', təzərrəfət'- 'sit on

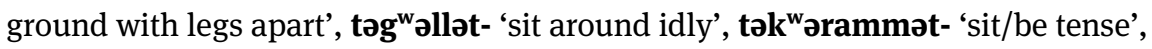
tənfərassəs- 'sit/be relaxed', tənk’obəlləl- 'sit on an undeserved (higher) place', and tənbərəkkək- 'kneel' can be listed as sitting verbs. The core meanings of sitting position and locatedness are associated with the roots of the verbs.

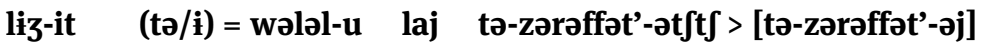

$$
\begin{aligned}
& \text { child-F at = floor-DEF on MID-sit.improperly-3sG.F } \\
& \text { 'The girl sat on the floor with legs apart.' }
\end{aligned}
$$

In example (4), the verb təzərəffət'- 'sit on the ground with legs apart' expresses the sitting position of the figure lizit 'girl' on the wələl 'floor'. In addition, it renders the notion of an improper manner of sitting. In the example, the spatial prepositions tə- or i- 'at' and the postposition laj 'on' show that the noun wələl 'floor' has a function of location. 


\subsubsection{Verbs of lying}

Verbs of lying characterize verbs denoting a lying position of the figure. The Amharic verbs təgaddəm- 'lie' and tənzərraga- 'lie sprawled'4 signify the lying position of the figure. Besides, the verbs təngalləl- 'lie on one's back' and tənbələbbəl- 'lie on one's belly' convey specific types of lying position (that is, supine and prone respectively).

$$
\begin{aligned}
& \text { Simagille-u to }=\text { alga-u laj to-gaddəm-ə } \\
& \text { elder-DEF } \quad \text { at }=\text { bed-DEF } \quad \text { on } \quad \text { MID-lie-3sG.m }
\end{aligned}
$$

In example (5), the root, /g-d-m/ 'lie' of the verb təgaddəm- 'lay' lexicalizes the

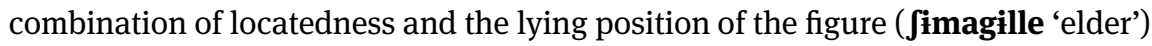
on the alga 'bed'. The roots of lying verbs in Amharic render the combination of two semantic elements: locatedness and the lying position. Therefore, the verbs derived from the roots are manner conflated.

\subsubsection{Verbs of hanging}

The term "verbs of hanging" refers to static verbs conveying the figure's positioning of being suspended. In Amharic, the verbs tont'ələt't'əl- 'being hung' and təsək'k'əl- 'being suspended' can be mentioned as verbs of hanging. The basic roots of these verbs are / $\mathbf{t}$ '-1-t'-1/ 'hang' which is extended to [n-t'-1-t'-1] by inserting the continuant $/ \mathbf{n} /$ and $/ \mathbf{s}-\mathbf{k}$ '-1/ 'suspend' respectively.

$$
\begin{aligned}
& \text { k'want'a-u } \\
& \text { (tə/i) = gəməd-u laj tə-sək'l-o-all >[ tə-sək' } \left.{ }^{w} \text { all }\right] \\
& \text { dry.strips.of.meat-DEF at = rope-DEF on PASS-Suspend.CVB-3SG.M-AUX } \\
& \text { 'The dry strips of the meat are hung on the rope.' }
\end{aligned}
$$

The verb təsək'l- 'be suspended' in (6) renders the semantic notions of locatedness plus the manner of hanging. In the example, the semantic category of a site is expressed by the adposition laj 'on'.

\subsection{Summary}

In Section 3 I described the semantics of Amharic static locative expressions by using Talmy's (1985, 2000, 2007) lexicalization pattern approach. Examples (1) through (6) show that the site component of a stationary location event is always

4 In the standard Amharic, it is pronounced as təzərraga- 'lie sprawled'. 
expressed by adpositions. Besides, the semantic component of locatedness conflated with a position of the figure can be encoded by a positional locative verb. This suggests that Amharic uses a satellite-framed pattern in static locative constructions. However, I do not claim that Amharic is a satellite-framed language because the material discussed in this paper does not include expressions of movement that are subsumed under Motion event. Regarding the variability of patterns of Motion constructions between static and movement expressions, the present study shows that Amharic uses satellite framing for static location. For movement expressions, other studies such as Wakasa (2016) have argued that Amharic uses a verb-framed strategy.

\section{Basic locative constructions}

Basic Locative Construction (BLC) refers to the most typical construction used in response to a where- search-question, i.e., 'Where is the figure with respect to the ground.' Languages may use a number of different locative descriptions in response to a "where" question. However, identifying BLC depends on the prototypical kind of scenes. ${ }^{5}$ Thus, it is the construction deployed to describe the location of an easily moveable inanimate figure in reference to a ground to which it is not attached (cf. Levinson and Wilkins 2006b: 16). ${ }^{6}$ Amharic has three constructions that are used as BLC. These are: (1) a construction with a generic locative verb ji-ggənn-all (< ji-t-gənjn-all) 'be found', (2) a construction with a copula nə'be', and (3) a construction with an existential copula all- 'exist' as in example (7).

The Amharic copulas nə- 'be' and all-" 'exist' are used in present-tense expressions while nəbbər- 'be.PST, exist.PST' is a suppletive form used in the pasttense expression of both nə- 'be' and all- (cf. Meyer 2011a: 1,196-1,197). Both (present tense) copulas are employed in locational expressions, accompanied by various suffixes indicating person, gender, and number (Baye 2016: 135).

When two or more constructions are candidates for BLC, Ameka and Levinson (2007: 852) suggest three criteria to identify the typical locative expression. The criteria include: (1) how the constructions are used to describe stereotypical versus

5 These are scenes in which (1) a figure is an easily moveable inanimate entity, (2) a ground is large compared to figure, relatively stationary (fixed or immobile), and not high animate, and (3) the relation between figure and ground is not too separated, not too attached, and not too nonstereotypical (Levinson and Wilkins 2006a: 515, 2006b: 16).

6 Therefore, constructions with positional verbs as in Section 3 while being locative constructions which can also answer 'where' questions are not basic locative constructions in Amharic because it is not employed in prototypical kind of scenes.

7 It is an existential copula but it can also be used in locational expressions. 
exceptional scenes, (2) which construction is used in negative locative statements, and (3) the frequency of use in the stimuli descriptions (Ameka and Levinson 2007: 852).

Based on the first criterion, it is found out that a construction that involves a generic locative verb may not be used while locating an animate figure, regardless of scene kinds. Besides, a construction that involves the existential copula all- is used for scenes characterized at level VI of the BLC hierarchy (cf. Ameka and Levinson 2007: 853), i.e., scenes involving the localization of moveable inanimate objects. However, it is not deployed for the following situations listed on the other levels of the BLC hierarchy: (a) figure is stuck or attached to ground, (b) figure is damage or negative space (e.g., crack), (c) figure is part of whole (part of ground), and (d) figure is clothing. On the other hand, a construction with the copula nəcovers the whole range of BLC hierarchy mentioned in Ameka and Levinson (2007: 853) and Levinson and Wilkins (2006b: 16); it is used to describe stereotypical scenes.

Following the second criterion, it is noted that a construction with the suppletive forms -dəll- 'is not' and jəll- 'does not exist' of the copulas nə- and all-, respectively, can be used in negative locative statements. While -dəll- has unrestricted contexts of use, jəll- is not natural in the contexts (a) - (d) in the preceding paragraph with respect to the BLC hierarchy. As a result, we can conclude that a construction with the copula verb nə- is a more typical construction in negative locative statements.

From the perspective of the third criterion, it is also noted that a construction with the verbal copula nə- is predominantly used. And the least frequent locative construction is a construction with the generic locative verb jigganjall 'is found'. See Table 2 for a summary of the frequency of each construction in material elicited with the use of the stimuli kit mentioned in Section 2.3.

Table 2: A comparison of the basic locative constructions.

To sum up, the above findings suggest that the typical BLC of Amharic is a construction with the verbal copula nə-, showing that Amharic is a type Ia language.

The BLC in Amharic is of the form: a noun phrase expressing figure followed by an adpositional phrase denoting site and finally the locative predicates (see the 
aforementioned predicates). The adpositional phrase can be made up of (i) the ground nominal and a spatial postposition, or (ii) a spatial preposition, ground nominal, and a postposition. ${ }^{8}$ In what follows, I will describe spatial prepositions and postpositions in separate subsections; then I will proceed to a discussion on how they co-occur.

\subsection{Spatial prepositions}

In the literature, the prepositions of Amharic including the spatial prepositions are treated in two different ways: (1) as independent words (Anbessa and Hudson 2007: 46-47; Baye 2016: 93; Leslau 1995: 597-616) (2) as semantic case markers (Baker and Kramer 2014: 144; Hetzron 1970: 308-315; Tremblay and Kabbaj 1990: 175). In this study, I treat them as independent words classified as prepositions.

In Amharic, basic location can be expressed by using the spatial prepositions kə, tə- and $\mathbf{i}$ - 'at'. ${ }^{9}$ These prepositions have a general locative function; they do not show specific types of topological relations between the figure and the ground. This means that they convey a dimensionless position of the figure. The distinction among the three involves dialect variation. Speakers of the Godzdzam variety (GA) in rural areas usually use tə- or i- interchangeably in situations where the noun denoting the ground begins with a consonant. In such a case, they serve as free variants. When the ground noun begins with a vowel, they may use tə-. Those speakers who live in towns and have exposure to 'standard' Amharic (henceforth SA) tend to use the preposition kə-. For illustration, consider utterances (7) and (8).
a. irsas-u $\mathbf{i} / \mathbf{t} \boldsymbol{\partial}=\mathbf{t}$ 'ərənbeza-u laj $\mathbf{n} \boldsymbol{\jmath}-\mathbf{u}$ pencil-DEF at $=$ table-DEF on COP-3SG.M 'The pencil is on the table.' (TRPS 59)
b. irsas-u kə=t'ərəp'eza-u laj nə-u pencil-DEF at = table-DEF on COP-3sG.M
'The pencil is on the table.' (TRPS 59)

(8)

$\begin{array}{lllll}\text { a. } & \text { marda-u } & \text { tə }=\text { angət-u-a } & \text { laj } & \text { nə-u } \\ \text { necklace-DEF } & \text { at }=\text { neck-Poss.3SG-F } & \text { on } & \text { COP-3SG.M } \\ \text { 'The necklace is on her neck.' (TRPS } & 51) & \end{array}$

8 Such constructions can be used interchangeably. A consultant can use such types of ground phrases in different utterances of the same TRPS stimulus.

9 In locative descriptions, such prepositions are not obligatory; they can be omitted. 


\begin{tabular}{|c|c|c|c|}
\hline b. dok’a-u & kə-angət-u-a & laj & nə-u \\
\hline necklace-DEF & at $=$ neck-Poss.3sG-F & on & COP-3SG.M \\
\hline
\end{tabular}

As shown in example (7) above, the ground noun t'ərənbeza 'table' begins with the consonant $/ \mathbf{t}$ ' . In such a case, those speakers who do not have exposure to SA use the locative prepositions to- and $\mathbf{i}$ - interchangeably as in (7a). In example (8) above, the ground noun angat 'neck' begins with a vowel and speakers do not use the morpheme $\mathbf{i}$-, instead they use to-. On the other hand, speakers who have exposure to SA use kə- both in consonant- and vowel-initial words, as in (7b) and (8b).

There is also another locative preposition bə- 'at', which has limited contexts of use. Based on the data I obtained, it is marginalized in BLC. It can be deployed in situations when a figure is firmly attached to the ground (e.g., stamp on the envelope) as well as when a figure is physically separated from the ground (e.g., fence around the house). However, such topological relations are not good candidates for BLC treatment (Levinson and Wilkins 2006a: 515). In such cases, the locative expression involves resultative constructions, as in (9).

tembir-u bə $=$ bost'a-u laj to-lat't'if-o-all
stamp-DEF at = post-DEF on PASS-glue.CVB-3SG.M-AUX
'The stamp is glued on the envelope.' (TRPS 03)

In example (9), the verb tələt't'əf- 'be glued' is a passive resultative verb expressing the result of gluing. In such an instance, the preposition bə- 'at' shows that the noun bost'a 'envelope' has the function of location at which tembir 'stamp' is placed.

In a copular construction, bə- 'at' can be used in contexts in which the ground is a bounded container and emphasis is on the container.

$\begin{array}{llll}\text { t'əlla-u } & \text { bə }=\text { bitfəre-u } & \text { wist' } & \text { nə-u } \\ \text { local.beer-DEF } & \text { at = glass-DEF } & \text { In } & \text { COP-3SG.M }\end{array}$

'The beer is in the glass.' (lit. 'The local beer is inside the glass.')

In this example, the preposition bə- shows that the ground bitfore 'glass' serves as a container of t'əlla 'local beer'. In such a case, speakers emphasize the container. The container itself is the location of t'əlla. However, bə- does not frequently occur in typical locative expressions in the Amharic variety of Godzdzam. 


\subsection{Spatial postpositions}

Amharic uses a considerable number of spatial postpositions to express the part of the ground where the figure is located. The postpositions may encode specific relational positions with reference to the ground. Amharic spatial postpositions may encode a region or a part of the ground at which figure is located (see Table 3).

Table 3: Amharic spatial postpositions.

\begin{tabular}{|c|c|c|c|}
\hline Form & Gloss & $\begin{array}{r}\text { Bowerman and } \\
\text { Pederson's (1992) } \\
\text { TRPS stimuli }\end{array}$ & Semantic conditions \\
\hline laj & 'at, on, top’ & $\begin{array}{r}1,3,4,5,7,8,9,10,11 \\
12,17,18,20,21,22\end{array}$ & $\begin{array}{l}\text { a. The figure is in contact with the } \\
\text { ground horizontally or vertically. } \\
\text { b. A figure sits or stands on the ground } \\
\text { but not covered by it. } \\
\text { c. A figure is anchored or stuck on the } \\
\text { ground. }\end{array}$ \\
\hline wist' & 'inside” & $2,11,14$ & $\begin{array}{l}\text { The figure is totally or partially covered } \\
\text { by the ground. }\end{array}$ \\
\hline wit 't $^{\prime}$ & 'outside’ & & The figure is outside of the container. \\
\hline zurija & 'around' & $15,54,67,71$ & $\begin{array}{l}\text { A figure encircles ground but does not } \\
\text { have physical contact with it. }\end{array}$ \\
\hline sir & 'under' & $16,24,49$ & The figure is below the ground. \\
\hline dar & ‘edge’ & 38 & $\begin{array}{l}\text { The figure is on the periphery of inani- } \\
\text { mate ground. }\end{array}$ \\
\hline mihal & 'center' & 19,60 & The figure is at the center of the ground. \\
\hline t’'af & 'tip’ & 20 & $\begin{array}{l}\text { The figure is on the tip of the vertically } \\
\text { or horizontally extended ground }\end{array}$ \\
\hline rasge & 'on the top of' & 65 & $\begin{array}{l}\text { The figure is at the top of the vertically } \\
\text { extended or lying headed body ground }\end{array}$ \\
\hline anat $^{10}$ & $\begin{array}{l}\text { 'crown of the } \\
\text { head' }\end{array}$ & 65 & $\begin{array}{l}\text { The figure is at the top of the vertically } \\
\text { extended ground. }\end{array}$ \\
\hline girge & $\begin{array}{l}\text { 'on the bot- } \\
\text { tom of' }\end{array}$ & & $\begin{array}{l}\text { The figure is at the bottom of the verti- } \\
\text { cally extended or headed and legged } \\
\text { body ground. }\end{array}$ \\
\hline $\begin{array}{l}\text { ga } \\
\text { zand }\end{array}$ & 'at' & 6 & $\begin{array}{l}\text { The figure is located in the region of } \\
\text { ground. }\end{array}$ \\
\hline
\end{tabular}

10 In Amharic, body part terms like anat 'crown of the head', ras 'head', fit 'face', dzərba/hwala 'back', igir 'foot, leg', gwadn 'rib', and sir 'root' are used as locative terms, such as 'top', 'front', 'side' 'behind/back', and 'bottom'. 
Table 3: (continued)

\begin{tabular}{|c|c|c|c|}
\hline Form & Gloss & $\begin{array}{r}\text { Bowerman and } \\
\text { Pederson's (1992) } \\
\text { TRPS stimuli }\end{array}$ & Semantic conditions \\
\hline t’igg & $\begin{array}{l}\text { 'next to, } \\
\text { corner of' }\end{array}$ & \multirow{5}{*}{$6,38,49$} & $\begin{array}{l}\text { The figure is next to the inanimate } \\
\text { ground. }\end{array}$ \\
\hline $\begin{array}{l}\text { at'əg əb } \\
\text { ak'rabbija }\end{array}$ & & & $\begin{array}{l}\text { The figure is close to the ground. } \\
\text { The figure is in the vicinity of the ground }\end{array}$ \\
\hline & 'front' & & $\begin{array}{l}\text { a) The figure is in front of a ground } \\
\text { having an intrinsic front and back } \\
\text { features. } \\
\text { b) The Figure is between the speaker } \\
\text { (observer) and ground }\end{array}$ \\
\hline $\begin{array}{l}\text { dzərba/ } \\
\text { hwala }\end{array}$ & 'back’ & & $\begin{array}{l}\text { a) The figure is at the back of a ground } \\
\text { having an intrinsic front and back } \\
\text { features }\end{array}$ \\
\hline & & & $\begin{array}{l}\text { b) the ground is between the figure and } \\
\text { the speaker (observer) }\end{array}$ \\
\hline
\end{tabular}

\subsubsection{Postpositions representing region}

The spatial postpositions zənd and ga 'at' are used to express the region of the ground object. zond is used by speakers who do not have exposure to standard Amharic, while ga is usually used by speakers of standard Amharic. Amharic deploys these two in contexts when the figure is co-located with the ground, e.g., 'wife' with 'family' as in example (11a). Using zond and ga 'at' in such contexts indicates that the ground is construed as a point in space. Consider the static locative expression in (11).
a. mift-e$$
\text { (tə/i) = betəsəb-ot } \int \mathbf{t} \int-\mathbf{u}-\mathbf{a}
$$
zond
at
nat (< nə-at)
wife-Poss.1sG
at = family-PL-POSs.3sG-F
COP.3SG.F
'My wife is at her family's place.' (introspection)

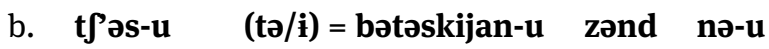
priest-DEF at = church-DEF at COP-3SG.M
'The priest is at the site of the church.'

\subsubsection{Postpositions representing specific topological relations}

Specific topological relations can be expressed by using those spatial postpositions representing the relative location of a figure in reference to the ground. These postpositions can also be categorized as nouns. This is because, in other contexts, they behave like other nominals by inflecting for gender and by taking 
definiteness and possession markers. When serving as locatives (Baye 2017: 21), they express the basic location of the figure with respect to the ground and they are not inflected. As such they behave like other spatial adpositions and can be treated as closed-class words. I thus prefer to designate them as 'spatial postpositions'. The overlap between adpositions and spatial nouns is also observed in other languages such as Lavukaleve, Ewe, Trumai, Basque, and English (cf. Levinson and Meira 2003: 493-94). Spatial postpositions can specify the location of the figure with respect to the ground. Amharic postpositions expressing specific topological relations between figure and ground entities cover the following semantic components: horizontality, verticality, containment (enclosure), distance, and support.

\subsubsection{Horizontality}

The horizontal relations that Amharic shows are front-back and central-peripheral relations. These are designated by the spatial postpositions fit 'front', fit_lə_fit 'in front of' and $\mathbf{h}^{\mathbf{w}}$ ala 'behind', dzərba 'back' respectively. ${ }^{11}$ These terms also have projective meanings, that is, they specify the angular location of the figure in reference to the ground entity. Central topological relations can be encoded by using mihal 'center'; the spatial information of the periphery is depicted by the spatial postpositions dar 'edge' and gwəodn > [gonn] 'side'.

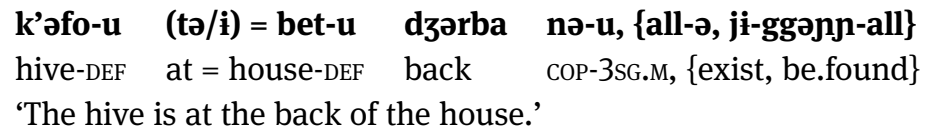

In (12), the spatial postposition dzərba 'back' expresses the specific type of horizontal relation (that is, back) between the figure object k'əfo 'hive' and the ground object bet 'house'.

\subsubsection{Verticality}

The semantic element of verticality is contrasted with the postpositions laj 'top', bəlaj 'above, over', mihal 'midsection', tat $\int \mathbf{t} \int>$ [taj] 'bottom' and bətat $\int \mathbf{t} \int>$ [bətaj] 'under, below'. When the figure is located on the ground entity and has

11 The locatives fit 'front' and $\mathbf{h}^{\mathbf{w}}$ ala 'back' can be interpreted in two ways: (1) from the perspective of the intrinsic features of ground and (2) from the perspective of the speaker (i.e., observer). In the first case, fit 'front' expresses a spatial relation where the figure is in front of a ground that has intrinsic front and back features, while $\mathbf{h}^{\text {wala }}$ 'back' represents a spatial relation where the figure is at the back of the ground with intrinsic front and back features. In the second case, fit is used in scenes where the figure entity is between the speaker and the ground object, and $\mathbf{h}^{\mathbf{w}}$ ala is employed in scenes where the ground is between the figure and the observer. 
contact with it, the postposition laj can be used; if a figure is located over the ground entity, the term bəlaj is preferred. If the figure is located at the middle of the vertically extended ground, the postposition mihal 'centre' can be employed; if the location of the figure is below the location of the ground entity, the term bətat $\int \mathbf{t} \int>$ [bətaj] 'under, below' is used. In addition, positional relations of body parts, anat 'crown of the head', rasge 'on the head of' and girge 'at the foot of', sir 'bottom, underneath, root' and wəgəb 'midsection, waist', can designate specific vertical topological relations.

\begin{tabular}{|c|c|c|c|}
\hline gum-u & $(\mathbf{t} ə / \mathbf{i})=$ tərara- $\mathbf{u}$ & bəlaj & nə-u \\
\hline fog-DEF & at $=$ mountain $-\mathrm{DEF}$ & above & COP-3SG.M \\
\hline
\end{tabular}

In (13), gum 'fog' (that is, figure) is located above the torara 'mountain' (that is, ground). This specific vertical relation is represented by the term bəlaj 'above'.

\subsubsection{Containment (enclosure)}

The spatial relation of containment is expressed by the postposition wist'/wift' 'in'. ${ }^{12}$ This postposition can be deployed in contexts when a figure is located at the interior portion of bounded ground, wherein the figure is partially or wholly enclosed by the bounded ground. It represents an enclosure conformation and a volume conformation. Hence, it encodes the notion of "enclosure" and "containment."
a. asa-u
$(\mathbf{t}$ /) $\mathbf{i})=$ tofa- $\mathbf{u}$
wist'
nə-u
fish-DEF
at $=$ pot-DEF
in
COP-3SG.M
'The fish is in the pot.' (TRPS 32)
b. bet-u (tə) $=$ at'ir-u wist' nə-u
house-DEF at $=$ fence-DEF in COP-3SG.M
'The house is in the fence.' (TRPS 60)

In example (14a), asa 'fish' is located in tofa 'pot', that is, a bounded ground object. Here, the ground (i.e., tofa) serves as a container of the figure (i.e., asa). The postposition wist' 'in, inside' depicts the notion of containment. In (14b), bet 'house' (i.e., the figure entity) is encircled by at'ir 'fence' (i.e., the ground entity). Here, the spatial postposition wist' expresses the semantic notion of containment. Indicating that the house is within the containing region of the fence., Thus the postposition wist' is associated with the semantic notions of, enclosure and containment.

12 The form wist' is widely used in the study area. However, some use the form wift'. 
In situations when the figure is located surrounding the ground object without physical contact, the postposition zurija 'around' is used, as illustrated in (15).

at'ir-u bə $=$ bet-u zurija $\quad$ nə-u
fence-DEF at = house- $\quad$ around
'The fence is around the house.' (TRPS 15)

Moreover, the spatial postposition wit $\int \mathrm{t} \int$ 'outside' is used in situations in which the figure is located at an exterior portion of a bounded ground without any contact.

\subsubsection{Distance}

Amharic has other types of spatial postpositions which can specify spatial proximity between figure and ground when they are separated in space. They represent a relative position of a figure in relation to a ground. For example, when a figure is proximal to ground at different levels of proximity, the postpositions like akkababi ‘surrounding area', gidim 'near', ak'irabbija 'vicinity', at’əgəb 'beside', and t'igg 'next to, corner of' are used. When the figure is distal to the ground entity,

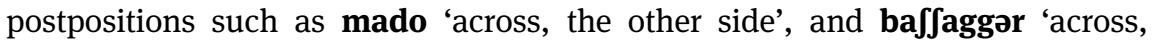

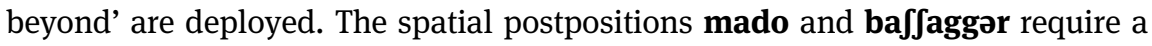
boundary between the figure and the ground. These postpositions designate gradable distance between the figure and the ground (Figure 1).

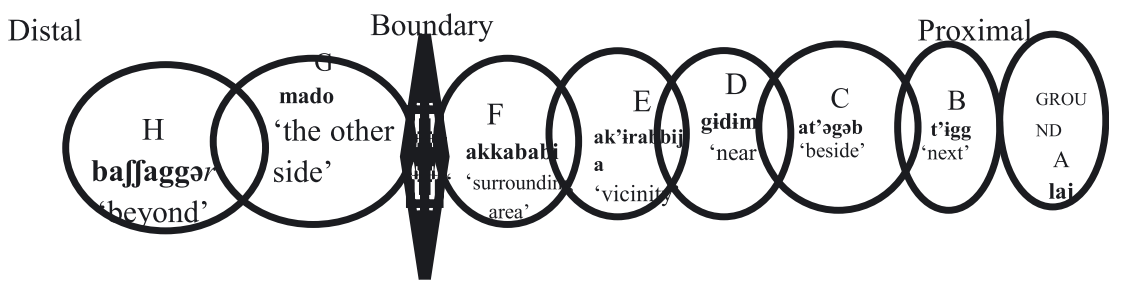

Figure 1: Amharic postpositions denoting spatial proximity and distance. ${ }^{13}$

Assuming that the site ' $A$ ' is the ground's location, the sites ' $B$ ' through ' $H$ ' express locations of the figure with different degrees of spatial proximity to the ground. When the figure is at 'A', the postposition laj 'on' can be used; if it is at the

13 Among five informants, one locates the postposition gidim 'near' in place of akkababi 'surrounding area.' These postpositions do not designate fixed, clear-cut measures of distance so speakers may alternate between different postposition to some extent. 
site ' $\mathrm{B}$ ', the term t'igg 'next to, corner of' is employed. If the figure is at 'C', at'əgəb 'beside, near' and in position ' $\mathrm{D}$ ' gidim 'near, thereabout' are used. When the figure is at E. F, G or H, ak'irabbija 'vicinity', akkababi 'surrounding area', mado

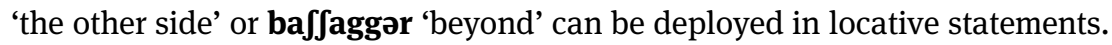
a. zaf-u
(tə/i) = bətəskjan-u t'igg
nə-u
tree-DEF at $=$ church-DEF next.to COP-3sG.m
'The tree is next to the church.' (TRPS 49)

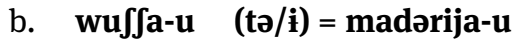
at'əgəb nə-u
dog-DEF at = place.to.spend.night-Poss3sG.m beside COP-3sG.m
'The dog is beside the doghouse.' (TRPS 06)

In example (16a), the figure zaf 'tree' is located on the very close range of the ground entity bətəskjan 'church'. To specify this spatial proximity, the post-

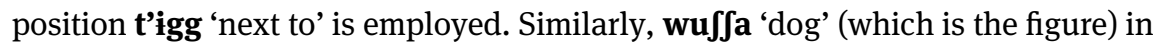
(16b) is located near the doghouse (that is the ground). To refer to such spatial proximity, at'əgəb 'beside' is used. In the examples, the ground is expressed with a complex adpositional phrase made up of a preposition, a ground noun, and a specific locative postposition.

$$
\begin{array}{llll}
\text { liz-u } & (\mathbf{t} \boldsymbol{} / \mathbf{i})=\text { isat-u } & \text { dar } & \text { nə-u } \\
\text { child-DEF } & \text { at = fire-DEF } & \text { edge } & \text { COP-3SG.M } \\
\text { 'The child is on the edge of the fire' } & \text { (TRPS 38) }
\end{array}
$$

In (17), dar 'edge' represents a specific topological relation in which the figure li3 'child' is located at a defined domain of the ground isat 'fire'. In the expression, emphasis is on isat; speakers construe the space next to isat 'fire' as the endpoint of its horizontal span, where liz and isat have a topological relation.

\subsubsection{Designating support relations}

In Amharic, the postposition laj 'on' can represent a support or contact kind of spatial (topological) relations. Based on Levinson and Meira's (2003: 489) hierarchy of adpositions, laj expresses the relations of support. In the case of (non)vertical support, laj represents the meaning of on (as discussed in the section on verticality above). It can be used in contexts when: (i) figure is in contact with ground horizontally or vertically, as in (18a, b); (ii) figure is anchored or stuck on ground as in (19) and (iii) figure is part of whole (part of ground) as in (20).
a. mət'af-u (tə/i) $=$ mədərdərija-u laj nə-u, book-DEF at = shelf-DEF on COP-3SG.M, \{exist, be.found 'The book is on the shelf.' (TRPS 08)
b. kot-u (tə/i) = məsk'ija-u laj nə-u, coat-DEF at $=$ hanger-DEF on COP-3SG.M, \{exist, be.found 'The coat is on the hanger.' (TRPS 09) 
The figure mət'af 'book' in (18a) is supported horizontally by mədərdərija 'shelf' whereas the figure kot 'coat' in (18b) is hung at məsk'ija 'hanger'. The topological relation between mət'af and mədərdərija in (18a) is horizontal while the spatial relation between kot and məsk'ja in (18b) is vertical (hanging position). Although the topological relations between figure and ground in (18a) and (18b) are not the same in the physical world, Amharic speakers construe them as similar and employ the same postposition laj to express the two spatial situations.

The postposition laj can also be used when the figure is fixed on the ground. In this case, there is no space between the figure and the ground. This implies that the figure covers some parts of the ground. Consider the following descriptions of picture 20 ('balloon on a stick') and 03 ('stamp on a letter') of TRPS.
a. finna-u
(tə/i) = Jiməl-u laj nə-u,
balloon-DEF at = stick-DEF on COP-3SG.M,
'The balloon is on the stick.' (TRPS 20)
b. tembir-u (tə/i) = bost'a-u laj nə-u,
stamp-DEF at = post-DEF on COP-3sG.M,
'The stamp is on the envelope.' (lit. 'The stamp is on the post.') (TRPS 03)

In the description of the scenes depicted in examples (19a) and (19b), the spatial postposition laj is used to express contact relations between the figures (finna 'ballon' and tembir 'stamp') and the grounds ( envelope'). Thus, Amharic does not have postpositions that can contrast spatial relations of (+/-) attachment by cord and (+/-) adhesion.

In addition, the Amharic postposition laj can be deployed to indicate the figure is in part-whole relation with the ground and to encode marks on the surface. This shows that the BLC can be used for the part-whole relation. Consider example (20).

$$
\begin{aligned}
& \text { t'ihuf-u (tə/i) = Jurrab-u laj nə-u, }\{\text { ji-ggənn-all }\} \\
& \text { writing-DEF at = shirt-DEF on COP-3SG.M, }\{\text { be.found }\} \\
& \text { 'The writing is on the shirt.' (TRPS 68) }
\end{aligned}
$$

In example (20), the figure t'ihuf 'writing', is part of the whole ground Jurrab 'shirt, vest'. The spatial postposition laj is used to indicate the t'ihuf is in partwhole relation with the Jurrab.

\subsubsection{Summary}

This subsection summarizes the discussion on the semantics of Amharic spatial postpositions. It is identified that Amharic spatial postpositions can show a region at which the figure is located (e.g., zond or ga 'at'). Also, they can specify spatial relations between the figure and the ground at a site. The spatial relations can 
denote horizontality, e.g., fit 'front', fit_lə_fit 'in front of', hwala 'back', dzərba 'back'; verticality, e.g., laj 'top', bəlaj 'above, over', mihal 'midsection', tat $\int \mathbf{t} \int$

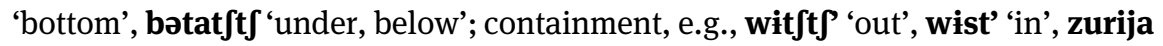
'around'; distance, e.g., akkababi 'surrounding area', gidim 'near' ak'irabbija 'vicinity', at’əgəb 'besides', and t'igg 'next to', mado 'across, the other side',

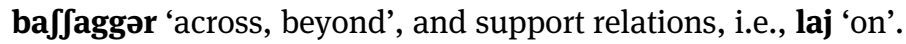

\subsection{Combinations of spatial adpositions in basic locative construction}

As discussed above, Amharic uses spatial adpositions (prepositions and postpositions) in BLC. The prepositions designate a general location of a figure while the postpositions can render the figure's specific location, spatial proximity, and region with respect to the ground. These adpositions may also be used in combination (cf. Anbessa and Hudson 2007: 80-81). Since locative prepositions do not specify the location of the figure with respect to the ground, they co-occur with spatial postpositions. For example, a scene involving 'cup on the table' (picture 01 of TRPS) can be described as follows.

$$
\begin{array}{llll}
\text { a. findzal-u } & (\mathbf{t} \boldsymbol{\prime} / \mathbf{i})=\mathbf{t} \text { 'ərənbeza-u } & \text { laj } & \text { nə-u, } \\
\text { porcelain.cup-DEF } & \text { at = table-DEF } & \text { on } & \text { COP-3SG.M, \{exist }\} \\
\text { 'The porcelain cup is on the table.' (TRPS 01) } &
\end{array}
$$

The basic location in (21) is constructed by using the general locative prepositions tə- or $\mathbf{i}$ - with the postposition laj. The prepositions tə- and i- express a spatial relation while the postposition laj denotes the spatial region of the ground object where the figure is located. The prepositions can be omitted without bringing about any appreciable semantic difference (compare example (21) with (22)).

$\begin{array}{llll}\text { findzal-u } & \text { t'ərənbeza-u } & \text { laj } & \text { nə-u, } \\ \text { porcelain.cup-DEF } & \text { table-DEF } & \text { on } & \text { COP-3SG.M, }\end{array}$

'The porcelain cup is on the table.'

Similar to the prepositions, postposition such as laj may be omitted in situations when the ground is a familiar location (e.g., home, market, church, school). In this case, site or the particular region of the ground is not specified as in (23b) or it can be interpreted from the context (from the nature of the ground) as illustrated in (23c), examples from introspection of author's native speaker intuition. In such cases, only a general imprecise location of the figure vis - à - vis the ground is expressed. 

a. X: jət no-h?
Where COP-2sG.M
'Where are you?'
b. Y: tə/i = bet nə- $\mathbf{n j}$
at $=$ house $\quad$ COP-1sG
'I am at home.' ()
c. bet (nə-jn)
house cop-1sG
'I am at home.' (lit. 'I am home.') (introspection)

The prepositions tə- or i- may be used without the spatial postposition laj as in (23b). In example (23c), there is no preposition or postposition to refer to the ground. However, (23c) is grammatical and the noun bet 'house' is interpreted as a location, a kind of elliptic construction that is perhaps made possible because the response is framed by the interrogative pronoun jət 'where' in (23a).

\section{Summary and conclusion}

The paper dealt with the structure and semantics of static locative expressions in the Godzdzam variety of Amharic. The analysis shows that Amharic employs spatial adpositions (prepositions, e.g., tə- and i- 'at', and postpositions like, laj 'at, on, top', wist' 'in', zənd 'at') to express different topological relations. Amharic verbs such as k’om- (< k’əwwəm-) 'stand', tək’əmmət'- 'sit', təgaddəm- 'lie' encode the semantic element of locatedness with manner related to positioning of the figure. So they are manner conflated static verbs. These verbs can be categorized into four types in terms of position assumed by the figure: (1) verbs of standing, (2) verbs of sitting, (3) verbs of lying, and (4) verbs of hanging. We also noted that Amharic static locative expressions have a satellite-framed pattern.

In BLC, Amharic uses spatial adpositions (prepositions, postpositions or a combination of the two) with a copula or a generic locative verb. The prepositions tə- and i- 'at' render the notion of general location of a figure. The postpositions designate different regions and parts of ground objects where the figure is located. They may encode: (a) relational positions of figure in reference to ground (e.g., dar 'edge', mihal 'center'), (b) relative spatial proximity (e.g., ak'irabja 'vicinity', at'əgəb 'beside'), (c) support or contact relations (e.g., laj 'on'), or (d) designate a less specific location such as region (e.g., zənd 'at').

The verbs used in Amharic BLC are the copulas nə- be' and all- 'exist' and the generic locative verb ji-t-gəjn-all > [ji-ggənj-all] 'be found'. A construction with a generic locative verb can be more natural for inanimate figures. Besides, a 
construction that involves the existential copula all- can be employed for prototypical scenes. But it is not used in following contexts: (a) figure is stuck or attached to ground, (b) figure is damage or negative space (e.g., crack), (c) figure is part of whole (part of ground), and (d) figure is clothing. On the other hand, a construction with the copula no- covers the whole range of basic locative hierarchy mentioned in Ameka and Levinson (2007: 853) and Levinson and Wilkins (2006b: 16). As a result, the typical basic locative expression in Amharic is a copular construction with nə-. From the perspective of a typology of locative predication, which is posited by Ameka and Levinson (2007: 852), Amharic falls under type Ia where a language uses a dummy verb in BLC.

\section{Abbreviations}

$\begin{array}{ll}1 & \text { first person } \\ 2 & \text { second person } \\ 3 & \text { third person } \\ \text { AUX } & \text { auxiliary } \\ \text { BLC } & \text { basic locative construction } \\ \text { COP } & \text { copula) } \\ \text { CVB } & \text { converb } \\ \text { DEF } & \text { definite } \\ \text { F } & \text { feminine } \\ \text { GA } & \text { Godzdzam Amharic } \\ \text { M } & \text { masculine } \\ \text { MID } & \text { middle voice } \\ \text { PASS } & \text { passive } \\ \text { PL } & \text { plural } \\ \text { POSS } & \text { possessive } \\ \text { SA } & \text { standard Amharic } \\ \text { SG } & \text { singular } \\ \text { TRPS } & \text { topological relations pictures series }\end{array}$

\section{References}

Ameka, Felix K. \& Stephen C. Levinson. 2007. Introduction: The typology and semantics of locative predicates: Posturals, positionals and other beasts. Linguistics 45(5/6). 847-871.

Anbessa, Teferra \& Grover Hudson. 2007. Essentials of Amharic. Kölon: Rüdiger Köppe.

Baker, Marc C. \& Ruth Kramer. 2014. Rethinking Amharic prepositions as case markers inserted at PF. Lingua 145. 141-172.

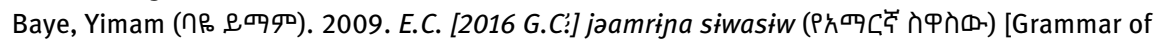
Amharic], 3rd edn. Addis Ababa: Addis Ababa University B.E. Press.

Baye, Yimam. 2017. Deictics in Amharic. Manuscript. 
Bezza, Tesfaw Ayalew. 2011. Causative of the 'passive' in Amharic. In Eyamba G. Bokamba, Ryan K. Shosted \& Bezza Tesfaw Ayalew (eds), Selected proceedings of the 40th annual conference on African linguistics, 53-64. Somerville, MA: Casadilla Proceedings Project.

Bowerman, Melissa \& Eric Pederson. 1992. Topological relations picture series. In Stephen C. Levinson (ed.), Space stimuli kit 1.2: November 1992, vol. 51. Nijmegen: Max Planck Institute for Psycholinguistics.

Debela, Goshu. 2007. Path in Oromo motion construction. Annual Publication of African Linguistics (APAL) 5. 73-88.

Hetzron, Robert. 1970. Toward an Amharic case-grammar. Studies in African Linguistics 1(3). 301-354.

Huang, Shuanfan \& Michael Tanangkingsing. 2005. References to motion events in six Western Australian languages: Toward a semantic typology. Oceanic Linguistics 44(2). 307-340.

Hudson, Grover. 1997. Amharic and Argoba. In Robert Hetzron (ed.), The Semitic languages, 457-485. London: Routledge.

Leslau, Wolf. 1995. Reference grammar of Amharic. Wiesbaden: Harrassowitz.

Levinson, Stephen C. \& David P. Wilkins. 2006a. Patterns in the data: A semantic typology of spatial description. In Stephen C. Levinson \& David P. Wilkins (eds.), Grammar of space: Explorations in cognitive diversity, 512-552. Cambridge: Cambridge University Press.

Levinson, Stephen C. \& David P. Wilkins. 2006b. The background to the study of the language of space. In Stephen C. Levinson \& David P. Wilkins (eds.), Grammar of space: Explorations in cognitive diversity, 1-23. Cambridge: Cambridge University Press.

Levinson, Stephen \& Sérgio Meira. 2003. 'Natural concepts' in the spatial topological domainadpositional meanings in cross-linguistic perspective: An exercise in semantic typology. Language 79(3). 485-516.

Mengistu, Amberber. 2000. Valency-changing and valency encoding devices in Amharic. In Robert M. W. Dixon \& Alexandra Y. Alkhenvald (eds.), Changing valency: Case studies in transitivity, 312-332. Cambridge: Cambridge University Press.

Mengistu, Amberber. 2010. The structure of the light verb construction in Amharic. In Mengistu Amberber, Brett Baker \& Mark Harvey (eds.), Complex predicates: Cross-linguistic perspectives on event structure, 291-318. Cambridge: Cambridge University Press.

Meyer, Ronny. 2006. Amharic as lingua franca in Ethiopia. Lissan: Journal of African Languages and Linguistics 20(1/2). 117-132.

Meyer, Ronny. 2007. Self-agentive motion verbs in Muher. Annual Publication of African Linguistics (APAL) 5. 1-18.

Meyer, Ronny. 2011a. Amharic. In Stefan Weninger (ed.), The Semitic languages: An international handbook, 1178-1212. Berlin: De Gruyter Mouton.

Meyer, Ronny. 2011b. The role of Amharic as a national language and an African lingua franca. In Stefan Weninger (ed.), The Semitic languages: An international handbook, 1212-1220. Berlin: De Gruyter Mouton.

$\mathrm{Ng}$, Kathleen Teresa. 2014. On the typology of basic locative constructions in Sinitic language. Proceedings of the 14th international symposium on Chinese languages and linguistics, 337-346. Taipei, Taiwan: Institute of Linguistics, Academia Sinica.

Pourcel, Stephanie \& Anetta Kopecka. 2005. Motion events in French: Typological intricacies. www.alslangulthese.free.fr/page-perse-telch/pourcel2c-kopecka-motion-events-infrecchtypological-inticacies.pdf (accessed 4 May 2016).

Slobin, Dan I. 2004. The many ways to search for a frog: Linguistic typology and the expression of motion events. In Sven Stromqivist \& Ludo Verhoven (eds.), Relating events in narratives, 
vol. 2: Typological and contextual perspective, 219-257. Mahwah: Lawrence Erlbaum Associates.

Slobin, Dan I. 2006. What makes manner of motion salient? Explorations in linguistic typology, discourse, and cognition. In Maya Hickmann \& Stephané Robert (eds.), Space in languages: Linguistic systems and cognitive categories, 59-81. Amsterdam: John Bejamins.

Talmy, Leonard. 1985. Lexicalization patterns: Semantic structure in lexical forms. In Timothy Shopen (ed.), Language typology and syntactic description, vol. 3: Typology and process in concept structuring, 57-149. New York: Cambridge University Press.

Talmy, Leonard. 2000. Toward a cognitive semantics, vol. 2: Typology and process in concept structuring. Cambridge, MA: MIT Press.

Talmy, Leonard. 2007. Lexical typologies. In Timothy Shopen (ed.), Language typology and syntactic descriptions, volume III: Grammatical categories and the lexicon, 2nd edn., 66-168. Cambridge: Cambridge University Press.

Talmy, Leonard. 2014. Main verb properties. In Thomas Fuyin Li (ed.), Languages and linguistics: Compodium of cognitive semantics, vol. 3, 1-25. New York: Nova Science Publisher.

Treis, Yvonne. 2007. Motion events in Kambaata. Annual Publication of African Linguistics (APAL) 5. 197-226.

Tremblay, Mireille \& Ouadia Kabbaj. 1990. The internal structure of PPs in Amharic. In John P. Hutchison \& Victor Manfredi (eds.), Current approaches to African linguistics, vol. 7, 167-178. Dordrecht: De Gruyter.

Wakasa, Motomichi. 2016. An analysis of complex event representation in Amharic texts. Asian and African Languages and Linguistics 10. 139-155.

Zelealem, Leyew. 2007. The Amharic dialects revisited. In Rainer Voigt (ed.), Akten des 7 internationalen Semitohamitistenknogresses Berlin 2004, 449-480. Aachen: Shaker.

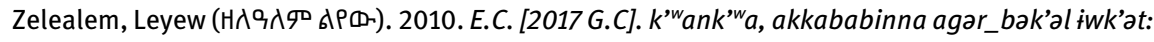
bagodzdzam amarinna laj jatakkora dasasa [Survey of language, environment and indigenous knowledge in Godzdzam]. Manuscript. Addis Ababa: Addis Ababa University. 